\title{
HUBUNGAN ANTARA KADAR HORMON DEHYDROEPIANDROSTERONE SULFATE (DHEAS) SERUM DENGAN AKTIVITAS PENYAKIT URTIKARIA KRONIS PADA PEREMPUAN
}

\author{
Herwinda Brahmanti ${ }^{\star 凶}$, Aunur Rofiq*, Mochammad Cholis*
}

\begin{abstract}
Abstrak
Urtikaria merupakan lesi kulit yang terdiri dari reaksi wheal dan flare. Sebanyak $15-20 \%$ penduduk pernah mengalami urtikaria dalam kehidupannya, dan $25 \%$ diantaranya mengalami urtikaria kronik. Kejadian urtikaria lebih banyak dijumpai pada perempuan. Adanya hubungan antara proses imunologis dan aktivitas neuroendokrin menjadi salah satu hipotesis yang mendasari patogenesis urtikaria. Ditemukannya peran DHEAS dalam fungsi imunomodulator dan antiinflamasi dapat menjadi dasar adanya peran dari terganggunya fungsi DHEAS akibat defisiensi dengan proses inflamasi pada urtikaria. Rancangan penelitian observasional potong lintang dilakukan untuk mengetahui adanya hubungan antara kadar hormon dehidroepiandrosteron sulfat (DHEAS) serum dengan aktivitas penyakit urtikaria kronis pada perempuan. Hasil uji Kruskall Wallis dengan post hoc Man Whittney menunjukkan adanya perbedaan yang bermakna antara aktivitas penyakit urtikaria dengan kadar DHEAS serum $(p=0,000)$. Analisis uji Spearman menunjukkan adanya korelasi negatif yang kuat antara aktivitas penyakit urtikaria dengan kadar DHEAS serum $(r=-0,933 ; p=0,000)$. Hal ini menunjukkan bahwa pada kadar yang lebih tinggi maka hormon DHEAS dapat bersifat protektif terhadap perburukan klinis urtikaria, dan sebaliknya pada kondisi urtikaria yang kronis terjadi penurunan kadar hormon DHEAS serum. Dapat disimpulkan bahwa pada wanita, ada hubungan antara kadar DHEAS serum dengan aktivitas penyakit urtikaria kronis. Hasil ini memperkuat kemungkinan terjadinya penurunan kadar DHEAS serum yang berperan dalam patogenesis urtikaria kronis.
\end{abstract}

Kata kunci: aktivitas penyakit, dehidroepiandrosteron sulfat serum, urtikaria kronis

\section{SERUM LEVEL OF DEHYDROEPIANDROSTERONE SULFATE (DHEAS) AND THE RELATIONSHIP WITH CHRONIC URTICARIAL IN WOMEN}

\begin{abstract}
Urticaria is a skin lesion consisting of wheal and flare reaction. As many as $15-20 \%$ of the population had experienced urticaria in their lives, and $25 \%$ had chronic urticaria. Urticaria is more common in women. The relationship between immunological and neuroendocrine activity became one hypothesis underlying the pathogenesis of urticaria. The role of DHEAS in the immunomodulatory and antiinflammatory effects underline the role of DHEAS deficiency in the pathogenesis of urticaria. A cross-sectional observational study design was conducted to determine the relationship between serum levels of dehydroepiandrosterone sulfate (DHEAS) with disease activity in women with chronic urticaria. The statistical analysis using Kruskall Wallis test with posthoc Man Whittney showed significant difference between urticaria disease activity with serum DHEAS levels $(p=0.000)$. The correlation analysis using Spearman test showed a strong negative correlation between disease activity of urticaria with serum DHEAS level $(r=-0,933 ; p=0,000)$. This results suggest that higher level of DHEAS may be protective against clinical worsening of urticaria. In the other hand, in chronic urticaria condition, the level of DHEAS will be decline. It can be concluded, there is a relationship between DHEAS and the disease activity of chronic urticaria. These results raise the possibility that the decreasing level of DHEAS serum may play a role in the pathogenesis of chronic urticaria.
\end{abstract}

Keywords: chronic urticaria, disease activity, serum dehydroepiandrosterone sulfate

* Lab./SMF IImu Kesehatan Kulit dan Kelamin FK UB-RSSA

E-mail: brahmanti_ub@yahoo.com 


\section{Pendahuluan}

Urtikaria merupakan lesi kulit yang terdiri dari reaksi wheal dan flare. Reaksi wheal merupakan bentuk manifestasi kulit dari reaksi edema lokal intrakutan yang dikelilingi oleh area eritem yang biasanya disertai dengan keluhan gatal. Klinis urtika ini dapat bertahan selama 30 menit hingga 36 jam dengan ukuran lesi bervariasi dari beberapa milimeter hingga 8 inci. Secara klinis, lesi urtika memucat jika ditekan akibat tertekannya pembuluh darah yang mengalami dilatasi. ${ }^{1}$

Angka kejadian urtikaria cukup tinggi. Sebanyak $15-20 \%$ penduduk pernah mengalami urtikaria dalam kehidupannya, dan $25 \%$ diantaranya mengalami urtikaria kronik. $^{2}$ Bulsenmeyer et al. (2008) melaporkan $0,1 \%$ sampai $3 \%$ penduduk USA dan Eropa menderita urtikaria kronik. ${ }^{3}$ Urtikaria merupakan salah satu dari 10 penyakit terbanyak di di Instalasi Rawat jalan (IRJA) Kulit dan Kelamin Rumah Sakit Umum Daerah (RSUD) dr. Saiful Anwar Malang berdasarkan laporan tahunan tahun 2011, dengan kunjungan sebanyak 244 kasus. Kejadian urtikaria lebih banyak dijumpai pada perempuan dibanding lakilaki. Kelainan kulit urtikaria ini tidak mengancam jiwa, tetapi secara nyata penyakit ini dapat mempengaruhi kualitas hidup penderita di segala aspek, meliputi pekerjaan, aktivitas belajar, fungsi sosial, dan hubungan dalam keluarga. ${ }^{4}$

Urtikaria bisa disebabkan oleh alergen tertentu seperti makanan, obat-obatan, bahan terapeutik, aeroallergen, racun hymenoptera, cacing, dan serpihan kulit hewan. ${ }^{1}$ Pada urtikaria kronik, lebih dari $70 \%$ kasus tidak diketahui penyebabnya. ${ }^{5}$ Banyak literatur yang berpendapat bahwa kemungkinan penyebab urtikaria kronik adalah reaksi psikofisiologik, alergi makanan, efek samping bahan tambahan makanan (food additive), infeksi jamur kulit (id reaction), dan helicobacterpylori, namun pendapat tersebut secara perlahan-lahan ditinggalkan karena dianggap keliru. Kaplan (2004) berpendapat bahwa bahan-bahan tersebut bukan sebagai penyebab urtikaria kronik. ${ }^{6}$ Vonakis dan Saini (2008) menyatakan bahwa faktor eksogen sangat kecil kemungkinannya sebagai penyebab urtikaria kronik. ${ }^{7}$

Patogenesis urtikaria berhubungan dengan peningkatan aktivasi sel mast dan berbagai reaksi inflamasi dan imunologis. Adanya hubungan antara proses imunologis dan aktivitas neuroendokrin menjadi salah satu hipotesis yang mendasari patogenesis urtikaria. Gangguan sistem neuroendokrinimunologis ini salah satunya dipicu oleh stres. ${ }^{8}$ Adanya perubahan keseimbangan hormonal dapat juga mempengaruhi proses imunologis dan fungsi kulit yang berperan dalam terjadinya urtikaria. Disamping stres, urtikaria juga dipengaruhi oleh faktor-faktor lain yang berhubungan dengan perubahan hormon seks misalnya menstruasi, kehamilan, menopause, penggunaan kontrasepsi hormonal, dan terapi sulih hormon. Tetapi, peran hormon seks endogen dan eksogen pada patogenesis urtikaria ini masih belum sepenuhnya diketahui. 9,10

Dehydroepiandosterone (DHEA) dan, derivat sulfatnya, dehydroepiandrosteron sulfate (DHEAS), merupakan prekusor androgen utama yang selanjutnya disintesis menjadi testosteron (T) dan dehydrotestoteron (DHT). Hormon DHEA(S) merupakan hormon androgen yang terbanyak ditemukan pada sirkulasi. ${ }^{11}$ Konsentrasi hormon ini lebih banyak ditemukan pada laki-laki dibanding perempuan. Konsentrasi DHEAS pada sirkulasi lebih besar 250 kali lipat dibandingkan DHEA. Selain itu, DHEAS memiliki kadar yang tetap sama sepanjang hari, sehingga merupakan alat diagnostik yang baik untuk penelitian ilmiah dan diagnosis klinis. ${ }^{12}$ Selain fungsi utamanya sebagai prekursor hormon androgen, beberapa fungsi fisiologis DHEAS(S) yang 
lain telah diteliti walaupun mekanisme secara pasti masih belum ditemukan. ${ }^{13}$

Data dan publikasi tentang hubungan antara perubahan hormon seks dan urtikaria masih sulit didapatkan. Ditemukannya peran DHEAS dalam fungsi imunomodulator dan antiinflamasi dapat menjadi dasar adanya peran dari terganggunya fungsi DHEA-S akibat defisiensi dengan proses inflamasi pada urtikaria. ${ }^{13,14}$ Berdasarkan fakta-fakta tersebut di atas, maka dilakukan penelitian untuk mengetahui hubungan antara kadar hormon dehidroepiandrosteron (DHEAS) dengan aktivitas penyakit urtikaria kronis pada perempuan.

\section{Bahan dan Metode}

Rancangan penelitian yang digunakan pada penelitian ini adalah observasional potong lintang yang bertujuan untuk mengetahui adanya hubungan antara kadar hormon dehydroepiandrosteron sulfate (DHEAS) serum dengan aktivitas penyakit urtikaria kronis pada perempuan.

Populasi penelitian adalah pasien yang berkunjung ke IRJA Kulit dan Kelamin RSUD dr. Saiful Anwar Malang. Subjek penelitian adalah pasien yang diambil dari populasi penelitian yang memenuhi kriteria eksklusi dan inklusi. Kriteria inklusi yaitu pasien perempuan yang terdiagnosis urtikaria kronis, berusia antara 20-30 tahun. Kriteria eksklusi yaitu sedang hamil, menyusui, menstruasi, sedang dalam terapi antihistamin, terapi kortikosteroid dosis tinggi (lebih dari $10 \mathrm{mg} / \mathrm{hari}$ ), kortikosteroid topikal, obat antidepresan (imipramin, fenotiazin), dopamin, clonidin selama 4 minggu terakhir, sedang dalam pengobatan yang dapat mempengaruhi aktivitas androgen, seperti estrogen, spironolakton, kontrasepsi hormonal, antiandrogen, kortikosteroid dan finasterid. Variabel penelitian ini adalah aktivitas penyakit urtikaria dan kadar hormon DHEAS serum.

Setiap pasien yang telah menjadi sampel penelitian dibuatkan status penderita urtikaria secara lengkap dan lembar pengumpul data. Setelah anamnesis dan pemeriksaan fisik, maka dilakukan pengukuran aktvitas penyakit dengan menggunakan metode UAS serta melakukan dokumentasi. Penegakan diagnosis dan penentuan aktivitas penyakit ditentukan oleh 2 orang pemeriksa pada hari yang sama.

Sampel penelitian selanjutnya diambil darahnya untuk diperiksa kadar hormon DHEAS serum dengan metode ELISA di Laboratorium Biomedik Fakultas Kedokteran Universitas Brawijaya Malang. Hasil data yang didapat dimasukkan dalam lembar pengumpulan data dan ditentukan hubungan antara kadar DHEAS serum dengan aktivitas penyakit urtikaria kronis.

Pengisian data dilakukan pada lembar pengumpulan data. Pengolahan data menggunakan program Statistical Package for Social Sciences (SPSS) versi 16. Uji komparatif dilakukan untuk mengetahui hubungan antara aktivitas penyakit urtikaria kronis dengan rerata kadar DHEAS serum menggunakan ANOVA jika sebaran data normal dengan alternatif uji Kruskal Wallis jika sebaran data tidak normal.

\section{Hasil}

Subjek yang bersedia ikut dalam penelitian ini adalah 32 orang dan memenuhi kriteria inklusi penelitian sebanyak 28 orang, sedangkan 4 orang subjek tidak dapat mengikuti penelitian karena 2 orang hamil, 1 orang menggunakan kontrasepsi hormonal dan 1 orang sedang dalam pengobatan kortikosteroid. 
Tabel 1. Karakteristik subjek penelitian

\begin{tabular}{lcc}
\hline \multicolumn{1}{c}{ Karakteristik } & Jumlah $\mathrm{n}(\%)$ & $p$ \\
\hline Usia (tahun) & 24,54 & 0,125 \\
Rerata & 3,045 & \\
SD (rentang nilai) & & 0,101 \\
\hline Lama sakit (bulan) & 13,79 & \\
Rerata & 10,117 & 0,156 \\
SD (rentang nilai) & $17(60,71)$ & \\
\hline Keluhan penyerta & & \\
Tidak ada & $9(32,14)$ & \\
Ada & $2(7,14)$ & \\
Angioedema & & \\
$\quad$ Sesak nafas & $13(46,43)$ & \\
\hline Pencetus & $9(32,14)$ & \\
Tidak diketahui & $1(3,57)$ & \\
Dingin & $5(17,86)$ & \\
Panas & $4(14,29)$ & \\
Makanan & $2(7,14)$ & \\
Psikologis & & \\
Infeksi & $15(53,57)$ & \\
\hline Penyakit atopik lain & & \\
Tidak ada & $3(10,71)$ & \\
Ada & $9(32,14)$ & \\
Asma & $1(3,57)$ & \\
Rinitis alergika (RA) & & \\
Asma \& RA & $17(60,71)$ & \\
\hline Atopik keluarga & $11(39,29)$ & \\
Tidak ada & & \\
Ada & & \\
\hline
\end{tabular}

Tabel di atas menunjukkan bahwa rerata usia subjek adalah $24,54 \pm 3,045$ tahun (20-30 tahun). Lama sakit subjek penelitian bervariasi mulai 2-36 bulan dengan rerata $13,79 \pm 10,117$ bulan. Manifestasi klinis penyerta urtikaria ada kasus ini terbanyak adalah angioedema $(32,14 \%)$, faktor pencetus terbanyak yang ditemukan adalah tidak diketahui $(46,43 \%)$.

Distribusi penyakit atopik lain yang menyertai didapatkan pada $13(46,43 \%)$ subjek, sedangkan $15(53,57 \%)$ subjek tidak didapatkan penyakit atopik lain. Asma didapatkan pada $3(10,71 \%)$ subjek, 9
$(32,14 \%)$ subjek dengan rhinitis alergika, dan sebanyak 1 (3,57\%) subjek dengan asma dan rhinitis alergika. Riwayat atopi pada keluarga didapatkan pada $11(39,29 \%)$ subjek. Uji homogenitas usia, lama sakit, keluhan penyerta, pencetus, penyakit atopi lain dan penyakit atopik pada keluarga terhadap kadar DHEAS serum dan UAS tidak menunjukkan perbedaan yang bermakna (nilai $p$ dapat dilihat pada Tabel 1).

Distribusi rerata DHEAS serum pada 28 subjek penelitian dengan menggunakan metode ELISA dapat dilihat pada Gambar 1. 


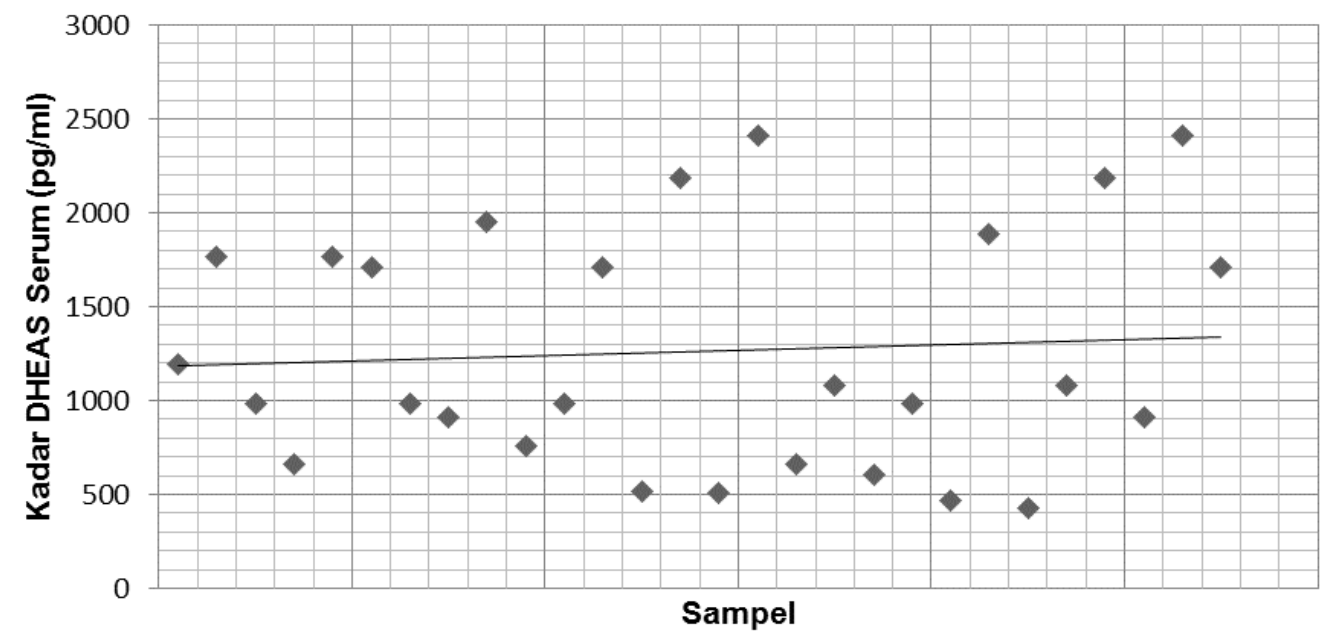

Gambar 1. Distribusi kadar DHEAS serum

Rerata kadar hormon dehydroepiandrosterone sulfate (DHEAS) serum adalah $1.263 \pm 632,48 \mathrm{pg} / \mathrm{ml}$. Kadar DHEAS serum tertinggi adalah 2.411,07 $\mathrm{pg} / \mathrm{ml}$ dan terendah adalah $428,71 \mathrm{pg} / \mathrm{ml}$. Hasil analisis normalitas data menunjukkan sebaran data yang tidak normal (ShapiroWilk test of normality; $p=0,020$ ).

Distribusi aktivitas penyakit urtikaria yang dinilai dengan menggunaan metode penghitungan UAS pada 28 subjek penelitian yang dinilai oleh dua penilai dapat dilihat pada Gambar 2.

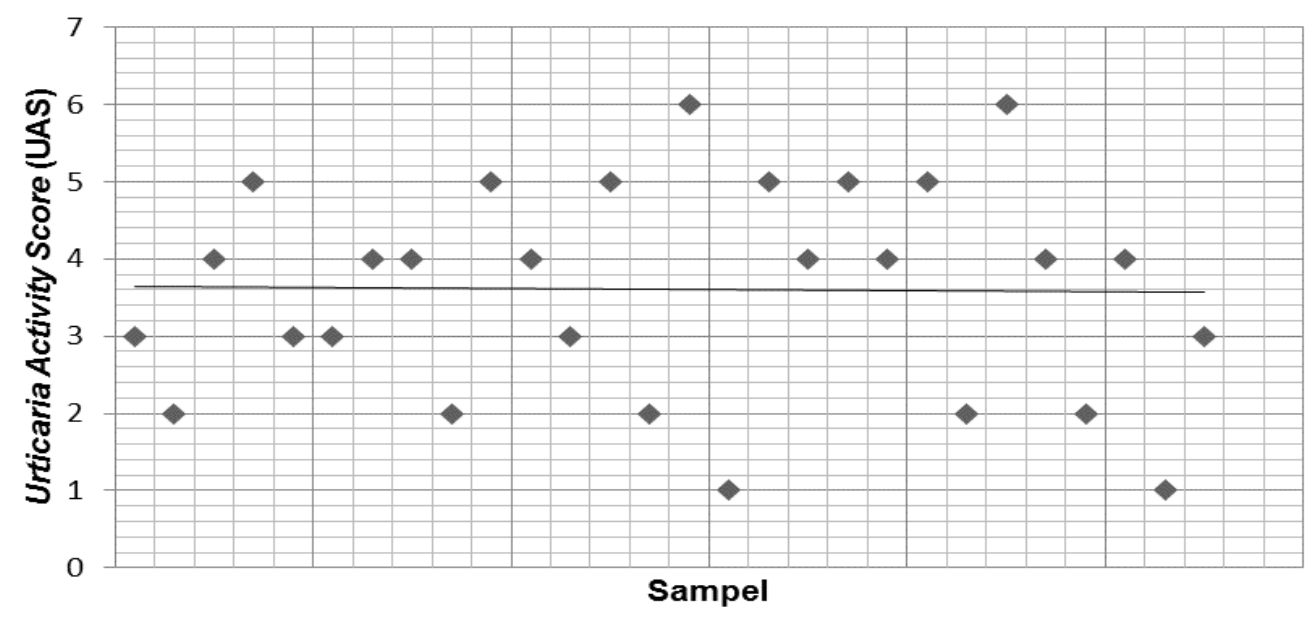

Gambar 2. Distribusi aktivitas penyakit urtikaria berdasarkan Urticaria Activity Score (UAS)

Rerata nilai Urticaria Activity Score (UAS) subjek adalah $3,61 \pm 1,38$. Nilai UAS tertinggi adalah 6 dan terendah adalah 1 . Hasil analisis normalitas data menunjukkan sebaran data yang tidak normal (ShapiroWilk test of normality; $\mathrm{p}=0,004)$.
Hubungan antara aktivitas penyakit urtikaria yang ditentukan melalui penilaian UAS dengan kadar DHEAS serum dapat dilihat pada Gambar 3. 


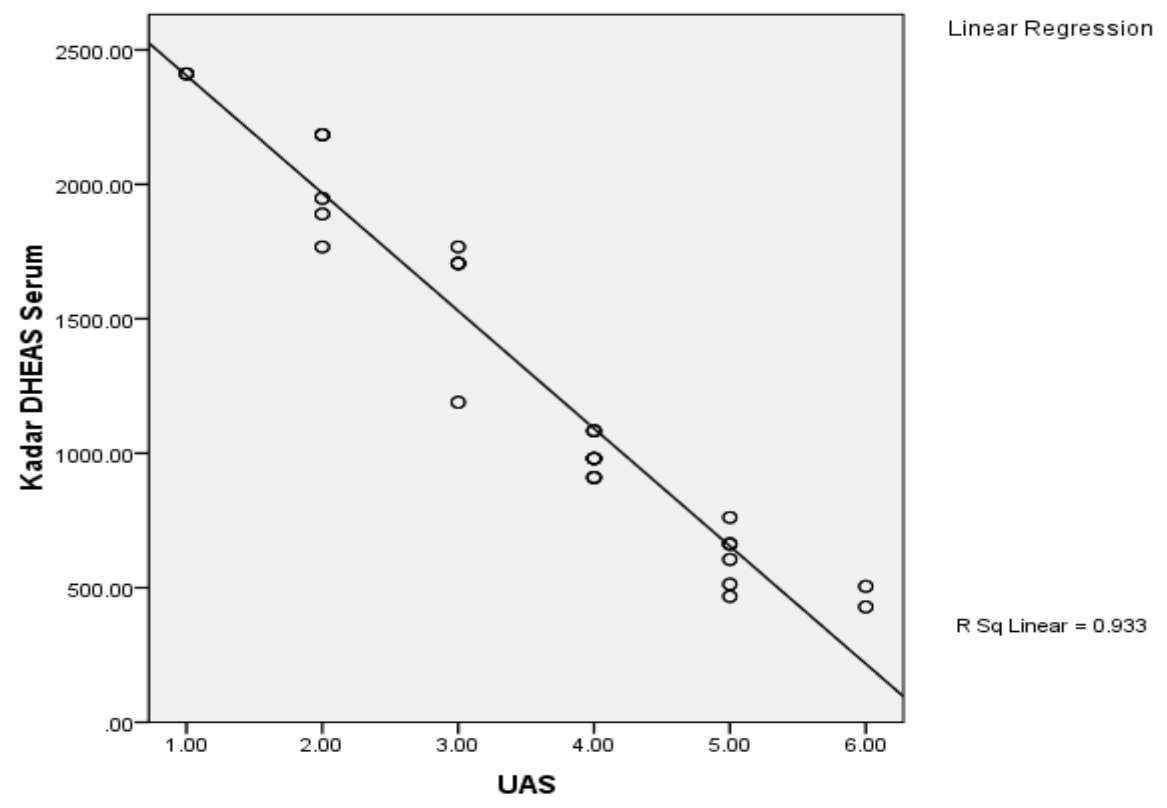

Gambar 3. Hubungan aktivitas penyakit urtikaria dengan kadar DHEAS serum

Hasil analisis uji beda dengan menggunakan Kruskall Wallis dengan uji post hoc Man Whittney menunjukkan adanya perbedaan yang bermakna antara aktivitas penyakit urtikaria dengan kadar DHEAS serum $(p=0,000)$ pada subjek penelitian. Analisis uji beda ini diperkuat dengan analisis korelasi dengan menggunakan uji korelasi non-parametrik Spearman $(r=$ $0,933, p=0,000$ ).

\section{Pembahasan}

Pemilihan populasi subjek berjenis kelamin perempuan ini berdasarkan pada beberapa penelitian, di antaranya yang dilakukan oleh Zuberbier dkk. tahun 2010 yang menyatakan bahwa angka kejadian urtikaria kronis lebih sering pada perempuan, terutama usia muda dengan jumlah sebesar $70,3 \% .{ }^{14}$ Rerata usia subjek penelitian ini adalah 20-30 tahun, hal ini berhubungan dengan parameter pengaruh hormon DHEAS terhadap urtikaria.
Puncak kadar tertinggi hormon DHEAS yaitu pada usia 20 hingga 30 tahun dan akan menurun hingga $20-30 \%$ dari kadar puncak pada usia 70 hingga 80 tahun. ${ }^{10,11}$ Oleh karena itu, dengan pemilihan populasi di rentang usia ini diharapkan efek hormon DHEAS terhadap penyakit urtikaria akan lebih terlihat. Angioedema dijumpai sekitar $30 \%$ menyertai gejala klinis urtikaria pada kasus urtikaria kronis. ${ }^{15,16}$

Faktor pencetus urtikaria umumnya sering dihubungkan dengan riwayat atopi pada diri dan keluarga (asma, rhinitis, eksim). Pada penelitian ini, faktor pencetus terbanyak yang ditemukan adalah tidak diketahui $(46,43 \%)$, hal ini sesuai dengan penelitian yang dilakukan oleh Carr dkk. (2012) dan Grattan dkk. (2012) serta beberapa penlitian lain yang menunjukkan bahwa sebagian besar urtikaria kronis biasanya pencetusnya masih belum diketahui (idiopatik).17,18 Beberapa jenis makanan juga dapat menjadi faktor pencetus, seperti makanan dengan protein dan bahan lain yang dicampurkan ke dalamnya (zat warna, penyedap rasa, dan pengawet). Pencetus lainnya adalah obatobat golongan tertentu, bahan fotosensitizer, bahan inhalan (serbuk bunga, spora jamur, 
debu, bulu binatang), bahan kontaktan (kutu binatang, serbuk tekstil, tumbuh-tumbuhan, bahan kimia, air liur binatang).

Selain itu, adanya faktor-faktor dari lingkungan juga dapat mencetuskan munculnya urtikaria, seperti trauma fisik (tekanan, goresan, getaran, suhu dingin, sinar matahari, exercise atau demam. Adanya infeksi, kelainan hormonal dan metabolik, keganasan juga dapat mencetuskan timbulnya urtikaria. Selain faktor-faktor di atas, faktor psikis seperti tekanan jiwa dapat memacu sel mast atau langsung menyebabkan peningkatan permeabilitas dan vasodilatasi kapiler. Pada penelitian ini, dari 28 subjek terdapat 4 subjek dengan pencetus psikologis dan terdapat 6 subjek penelitian lain yang bersedia untuk dikonsultasi ke bagian psikiatri, untuk menganalisis kemungkinan faktor psikis sebagai pencetus urtikaria kronis. Hasil pemeriksaan status psikiatri menunjukkan bahwa 4 dari 10 subjek yang diperiksa menderita neurosa (kecemasan).

Hasil analisis menunjukkan adanya korelasi negatif yang bermakna $(r=-0,933$; $p$ $=0,000)$ antara aktivitas penyakit urtikaria dengan kadar DHEAS serum. Hal ini menunjukkan bahwa pada kadar yang lebih tinggi, hormon DHEAS dapat bersifat protektif terhadap perburukan klinis urtikaria atau kondisi urtikaria yang kronis menyebabkan turunnya kadar hormon DHEAS serum. Hasil penelitian ini sesuai dengan penelitian yang dilakukan oleh Fathy dkk. (2009) yang memperkuat kemungkinan bahwa terjadinya penurunan kadar DHEAS serum berperan dalam patogenesis urtikaria kronis.

Sifat protektif dari hormon DHEAS telah dibuktikan pada beberapa peneltian sebelumnya. Pertama, Kaperska (2011) menunjukkan bahwa DHEAS mempunyai beberapa fungsi imunomodulator, yaitu dengan mensupresi peningkatan IgE dan IL6 pada beberapa penyakit alergi dan kelainan imunologis. ${ }^{12}$ Selain itu, DHEAS juga mempunyai efek hambatan pada sitokin
Th2. ${ }^{19}$ Kedua, rendahnya kadar DHEAS serum juga ditunjukkan pada penelitian yang dilakukan oleh Kaperska.8,9 Pada masa remisi urtikaria kronis, kadar DHEAS serum meningkat pada pasien yang sama hingga kadar yang mendekati kadar DHEAS pada populasi normal. Hal yang belum terjawab dari penelitian Kaperska (2008) adalah apakah peningkatan kadar DHEAS disebabkan oleh perbaikan klinis urtikaria atau sebaliknya. 8,9 Hal ketiga, penurunan kadar DHEAS sering kali dijumpai pada kondisi inflamasi kronis. ${ }^{7-9,19}$ Secara umum, DHEAS mempunyai kemampuan untuk secara langsung menghambat proses inflamasi di sekitar pembuluh darah dan hambatan aktivasi komplemen jalur klasikal. Pada urtikaria kronis, terjadi aktivasi sel endotelial yang disebabkan oleh mediator inflamasi dan sitokin, serta peningkatan pelepasan histamin yang diperantarai salah satunya oleh $\mathrm{C} 5 \mathrm{a} .7,20$

\section{Kesimpulan}

Semakin tinggi kadar hormon dehydroepiandrosterone sulfate (DHEAS) serum, semakin rendah aktivitas penyakit urtikaria kronis pada perempuan.

\section{Saran}

$$
\begin{gathered}
\text { Perlu dilakukan penelitian pada } \\
\text { populasi yang sama dengan }
\end{gathered}
$$
membandingkan kadar DHEAS pada pasien urtikaria kronis dan pada populasi normal untuk mengetahui batas normal kadar DHEAS serum pada populasi penelitian yang sama. Perlu dilakukan penelitian lanjutan yang menganalisis pengaruh faktorfaktor hormonal lain seperti kortisol dan prolactin, yang diketahui berhubungan dengan DHEAS, terhadap urtikaria kronis. Perlu dilakukan penelitian lebih lanjut tentang efek pemberian DHEAS secara in vitro pada aktivitas sel mast, sehingga dapat dikembangkan terapi DHEAS pada urtikaria kronis. 


\section{Daftar Pustaka}

1. Kaplan AP. Urticaria and Angioedema. Di dalam: Wolff L, Goldsmith LA, Katz SI, Gilchrest BA, Paller AS, Leffel DJ. Fitzpatrick's Dermatology in General Medicine. $7^{\text {th }}$ Edition. New York: McGraw Hill. 2008. 37: P 330-343.

2. Leznoff A. Chronic Urticaria. Canadian Family Physician. 2008; 44:2170-2176.

3. Bunselmeyer B, Laubach HJ, Schiller M, Stanke M, et al. Incremental BuildUp Food Challenge-A New Diagnostic Approach to Evaluate Pseudoallergic Reactions in Chronic Urticaria: A Pilot Study. Clinical and Experimental Allergy. 2008; 39(1):116-126. https://doi.org/10.1111/j.1365-

2222.2008.03110.x

4. Weldon DR. Quality of Life in Patient with Urticaria. Allergy Asthma Proc. 2006; 27(2):96-99.

5. Buss YA, Garrelfs VC, Sticherlig M. Chronic Urticaria - Which Parameters are Pathogenetically Relevant? A Retrospective Investigation of 339 Patients. JDDG. 2007; 5(1):22-27.

6. Kaplan AP. Chronic Urticaria: Pathogenesis and Treatment. Journal Allergy Clinical Immunology. 2004; 114(3): 465-474.

7. Vonakis BM, Saini SS. New Concepts in Chronic Urticaria. Curr opin immunol. 2008; 20(6):709-716.

8. Kasperska-Zajac A. Does Dehydroepiandrosterone Influence the Expression of Urticaria?-a Mini Review. Inflammation. 2011.34(5):3626. doi: 10.1007/s10753-010-9242-z

9. Kasperska-Zajac A, Brzoza Z, Rogala B. Dehydroepiandrosterone and Dehydroepiandrosterone Sulphate in Atopic Allergy and Chronic Urticaria. Inflammation. 2008; 31(3):141-5.

10. Kasperska-Zajac A., Z Brzoza, and B Rogala. Sex Hormones and Urticaria. Journal of Dermatological Science. 2008; 52(2):79-86.
11. Kroboth PD, Salek FS, Pittenger AL, Fabian TJ, Frye RF. DHEA and DHEAS: A Review. J Clin Pharmacol. 1999; 39:327-348.

12. Leowattana W. DHEAS as a New Diagnostic Tool. Clinica Chimica Acta. 2004; 341:1-15.

13. Dillon JS. Dehydroepiandrosterone, Dehydroepiandrosterone Sulfate and Related Steroids: Their Role in Inflammatory, Allergic and Immunological Disorders. Curr Drug Targets Inflamm Allergy. 2005; 4:37785.

14. Traish AM, Kang P, Saad F, Guay AT. Dehydroepiandrosterone (DHEA)-A Precursor Steroid or an Active Hormone in Human Physiology. J Sex Med. 2011; 8:2960-82.

15. Zuberbier $T$, Balke $M$, Worm $M$, Edenharter G, and Maurer M. Epidemiology of Urticaria: a Representative Cross-Sectional Population Survey. Clin and Exp Derm. 2010; 35:869-873.

16. Ozdemir O. Idiopathic (Autoimmune) Chronic Urticaria. Allergy Asthma Proc. 2006; 27:431-4.

17. Zuberbier $T$, Asero R, Bindslev-Jensen C, Canonica GW, Church MK, Giménez-Arnau A, et al. EAACI/GA(2)LEN/EDF/WAO Guideline: Definition, Classification and Diagnosis of Urticaria. Allergy. 2009; 64:1417-26.

18. Carr TF, Saltoun CA. Urticaria and Angioedema. Allergy Asthma Proc. 2012; 33(3):S70-2.

19. Grattan C. The Urticarias: Pathophysiology and Management. Clin Med. 2012; 12(2):164-7.

20. Sudo N, Xin $Y$, and Kubo C. Dehydroepiandrosterone Attenuates the Spontaneous Elevation Serum $\lg E$ Level in NC/Nga Mice. Immunol Lett. 2001;79(3):177-179. DOI: 10.1016/S0165-2478(01)00285-1 